PAWEŁ TURCZYŃSKI

DOI : $10.14746 /$ rie.2015.9.16

Uniwersytet Wrocławski

\title{
Rola Unii Europejskiej w negocjacjach nad irańskim programem atomowym
}

\section{Wprowadzenie - geneza irańskiego programu nuklearnego}

Obalenie w 1979 r. irańskiego szacha Mohammada Rezy Pahlawiego przez ajatollaha Rudollaha Chomeiniego oznaczało nie tylko zmianę formy rządów (republika zamiast cesarstwa), ale też wyraźne wyizolowanie się Iranu ze społeczności międzynarodowej. Proklamowana 1 kwietnia 1979 r. Islamska Republika Iranu (IRI) bardzo głęboko zakwestionowała porządek międzynarodowy, deklarując się jako krzewiciel nowego ładu, lepiej odpowiadającego potrzebom muzulmanów (Coville, 2009, s. 39-40, 175-179). R. Chomeini szukał dla społeczności muzułmańskiej nowego miejsca na arenie międzynarodowej: w jego koncepcji kopiowanie jakichkolwiek rozwiązań politycznych od „Wielkiego Szatana” (jak nazywał USA), czy od „Państwa Szatana” (jakim miał być ówczesny ZSRR) było bezcelowe ${ }^{1}$. Dla muzułmanów optymalnym ustrojem miałaby być uwspółcześniona wersja pierwotnej wspólnoty wiernych, na wzór tej, jaką stworzył wokół siebie w VII w. Mahomet.

W swojej polityce zagranicznej IRI szczególnie akcentowała niezależność od sił zewnętrznych - połączoną z gotowością naruszania tych norm prawa międzynarodowego, które w jej opinii Zachód stworzył we własnym kregu kulturowym, a następnie narzucił muzułmanom ${ }^{2}$. Powstanie IRI oznaczało wyzwanie rzucone wszystkim państwom muzułmańskim - i zachętę dla ich społeczeństw, aby obalały swoje rządy, budując ustroje na wzór irański ${ }^{3}$.

Pośrednim skutkiem powstania IRI była wojna z Irakiem (1980-1988), który zaatakował zanarchizowany Iran, licząc na zdobycze terytorialne, a także na poparcie społeczności międzynarodowej w walce $z$ państwem kontestującym istniejący ład. Pomimo ogromnych strat wojna nie przyniosła żadnej ze stron zwycięstwa, aczkolwiek większość państw trzecich sprzyjała Irakowi ${ }^{4}$.

1 Z punktu widzenia muzulmanów komunistyczny ZSRR, zwalczajacy islam w imię ateizmu, wysyłający wojska do Iranu w 1941 r. czy do Afganistanu w 1979 r., był kontynuatorem carskiej Rosji. która od XVIII w. również prowadziła ekspansję na ziemie muzułmańskie - $i$ też był częścią Zachodu.

2 Pogwałceniem podstawowych zasad prawa międzynarodowego było dwukrotne okupowanie (najpierw przez islamskie bojówki w 1979 r., później przez siły rewolucyjne w 1980 r.) ambasady amerykańskiej i zatrzymanie jej personelu jako zakladników - islamiści chcieli znaleźć dowody na uzależnienie obalonego szacha od amerykańskiej kurateli.

3 W 1981 r. radykalowie islamscy zamordowali prezydenta Egiptu, Anwara Sadata, mszcząc się w ten sposób za zawarcie przez niego w 1978 r. pokoju z Izraelem.

${ }^{4}$ W Iranie mogło to wzmagać poczucie osaczenia, tym bardziej że w konflikt wmieszaly się Stany Zjednoczone, zabiegające o bezpieczeństwo zlóż ropy i szlaków handlowych w Zatoce Perskiej. 
Na czele IRI aż do śmierci w 1989 r. stał R. Chomeini, pełniący funkcję Najwyższego Prawnika Muzułmańskiego, kontrolującego zgodność prawa stanowionego przez parlament, rząd i prezydenta z Koranem - a zatem jego legalność (Parsi, 2013, s. 10-11). Kolejnym Najwyższym Prawnikiem Muzułmańskim został - pełniący tę funkcję po dziś dzień - Ali Chamenei (w latach 1981-1989 prezydent Iranu).

IRI „odziedziczyła” aspiracje nuklearne jeszcze po rządach szacha (elektrownia jądrowa w Buszehr, której budowę rozpoczęto w 1975 r., a przerwano po rewolucji islamskiej), ale wznowiła program atomowy dopiero pod koniec lat 80. Koniec zimnej wojny i presja Stanów Zjednoczonych utrudniała prace nad tym projektem - zwłaszcza gdy sąsiedni Irak po wojnie o Kuwejt w latach 1990-1991 został objęty międzynarodowymi sankcjami i zakazem budowy broni masowego rażenia. „Iran rozpoczął starania o normalizację stosunków z krajami europejskimi, traktując je jako przeciwwagę dla konfrontacyjnych relacji z USA i Izraelem. Europa stała się priorytetowym kierunkiem irańskich starań o legitymizację reżimu, pozyskanie nowoczesnych technologii oraz inwestycji na modernizację gospodarki. [...] kwestia stosunku zjednoczonej Europy do Iranu stała się jednym $\mathrm{z}$ wiodących zagadnień polityki zagranicznej krajów EWG (później UE), a kraje te stały się głównym partnerem handlowym Iranu" (Ćwioro, 2009, s. 108).

Aby potwierdzić pokojowy charakter swojego programu atomowego Iran w $1992 \mathrm{r}$. zaprosił na inspekcję przedstawicieli Międzynarodowej Agencji Energii Atomowej (MAEA) i uzyskał akceptację ze strony jej ówczesnego dyrektora generalnego, Hansa Blixa. Iran zapowiedział dokończenie budowy elektrowni jądrowej w Buszehr: wprawdzie Niemcy, będące pierwotnym kontrahentem, w 1993 r. wycofały się ze współpracy, ale w 1995 r. obiecała swoją pomoc Rosja. W tym okresie wydawało się, że irańska polityka wewnętrzna i zagraniczna ulega liberalizacji - w 1997 r. wybory prezydenckie wygrał Mohammad Chatami. W tym też czasie pomiędzy UE a Iranem ustanowiona została polityka „konstruktywnego dialogu” (Posch, 2006, s. 99-100). Widoczny był postęp w bilateralnych relacjach polityczno-gospodarczych - Iranowi zależało zwłaszcza na dostępie do wysokich technologii (w szczególności militarnych) oraz na eksploatacji złóż ropy przez europejskie firmy (Coville, 2009, s. 195-198).

Celami prowadzonego przez UE dialogu politycznego były: ochrona interesów państw Unii w Iranie poprzez wzmocnienie politycznych stosunków bilateralnych oraz rozwój wymiany i współpracy gospodarczej; poparcie dla reform wewnętrznych w tym kraju; konstruktywne zaangażowanie Iranu jako ważnego aktora regionalnego w rozwiązywanie kryzysu bliskowschodniego, a także w międzynarodową kampanię antyterrorystyczną i we wsparcie nieproliferacji BMR (Ćwioro, 2009, s. 111-112). Należy zauważyć, że to ocieplenie wzajemnych relacji irańsko-unijnych nakładało się na pogorszenie (i tak bardzo złych od 1979 r.) stosunków Iranu z USA. Na początku 1998 r.

W 1988 r. podczas jednego z takich patroli amerykański krążownik omylkowo zestrzelil irańskiego Airbusa z 290 osobami na pokładzie.

5 W międzyczasie w 1997 r. stosunki te załamaly się po tzw. „Sprawie Mykonos”: niemiecki sąd uznał, że za dokonane w 1992 r. w berlińskiej restauracji „Mykonos” morderstwo lidera kurdyjskiej opozycji odpowiada szef irańskich służb specjalnych - i zażądał wydania za nim międzynarodowego listu gończego. 
Kongres USA powołał komisję ds. oceny zagrożenia Stanów Zjednoczonych rakietami balistycznymi (zwaną od nazwiska przewodniczącego „Komisją Donalda Rumsfelda"). W raporcie z 15 lipca $1998 \mathrm{r}$. komisja ta uznała, że zagrożenie atakiem rakietowym na USA jest coraz większe, a jednym z jego autorów może być właśnie Iran, który wzmacniał swój arsenał BMR - broni masowego rażenia, a wkrótce potem 25 września 1998 r. zaprezentował rakietę Shahab-3 o zasięgu niemal 2000 km (Turczyński, 2012, s. $42-43)$.

Program nuklearny Teheranu ponownie zainteresował MAEA, gdy 14 sierpnia 2002 r. irańska opozycja ujawniła za granicą istnienie dwóch nieznanych wcześniej obiektów - zakładu wzbogacania uranu ${ }^{6}$ w Natanz i wytwórni ciężkiej wody w Arak. Ponieważ działo się to już podczas ,wojny z terroryzmem” i w sytuacji, gdy o nielegalną produkcję broni masowego rażenia oskarżano sąsiedni Irak, MAEA przeprowadziła kolejną inspekcje. W jej trakcie m.in. odkryto w Natanz silnie wzbogacony uran, co poddawało w wątpliwość pokojowy charakter irańskiego programu atomowego (Ehteshami, 2006, s. 77-82).

Już po zajęciu Iraku przez siły USA i ich sojuszników, 6 czerwca 2003 r. szef MAEA Mohamed El Baradei raportowal, że Iran zaniedbał informowania o swoich osiagnnięciach i posiadanych materiałach nuklearnych, nie uznał jednak, że pogwałcono Traktat o Nierozprzestrzenianiu Broni Jądrowej (Non Proliferation Treaty, NPT) z 1 lipca 1968 r. ${ }^{7}$ Stany Zjednoczone najpierw domagały się nałożenia przez RB ONZ sankcji wobec Iranu, ale później poparły propozycję grupy EU 3, by dać Iranowi czas na pełne ujawnienie programu nuklearnego (miałby się też zgodzić na niezapowiedziane inspekcje MAEA).

Sama UE, która wiosną 2003 r. dramatycznie podzieliła się w sprawie poparcia bądź potępienia amerykańskiej interwencji w Iraku, podjęła w sprawie irańskiego programu atomowego działania dyplomatyczne. W jej imieniu przedstawiciele Francji, Niemiec i Wielkiej Brytanii (tzw. grupa EU 3), koordynujący swoje prace z unijnym Wysokim Przedstawicielem ds. Polityki Zagranicznej i Bezpieczeństwa (WP PZB) Javierem Solaną, podjęli rozmowy $z$ Iranem, aby uzyskać wyjaśnienia na temat charakteru jego badań nuklearnych. Wśród krajów UE pojawiały się rozbieżności dotyczące polityki wobec Iranu: Francja, Niemcy, Włochy i Hiszpania z uwagi na swoje interesy gospodarcze opowiadały się za zacieśnianiem kontaktów politycznych z Teheranem, natomiast bardziej wstrzemięźliwe były: Wielka Brytania, Holandia oraz kraje skandynawskie. Iran ze swej strony starał się wygrywać te różnice, jak również animozje pomiędzy USA i UE (Parsi, 2013, s. 18).

${ }^{6}$ Energię nuklearną pozyskuje się z izotopu uranu U-235, który stanowi mniej niż 1\% ogólnej ilości tego pierwiastka w stanie naturalnym. Na potrzeby cywilnej energetyki jądrowej wykorzystuje się uran niskowzbogacony, w którym izotop U-235 stanowi 3-5\%. Uran wysokowzbogacony musi zawierać ponad 20\% izotopu U-235 i może być wykorzystywany w celach militarnych (aczkolwiek jego efektywność jest wówczas niska). Do glowic bojowych stosuje się uran, w którym izotop 235 stanowi co najmniej $85 \%$.

7 International Atomic Energy Agency (LAEA), Board of Governors (BoG), Implementation of the NPT safeguards agreement in the Islamic Republic of Iran, Report by the Director General. GOV/2003/40, Date: 6 June 2003, Derestricted 19 June 2003. 


\section{Pierwsze propozycje negocjacyjne UE}

Dnia 21 października 2003 r. ministrowie spraw zagranicznych Iranu oraz grupy EU 3 wynegocjowali tzw. Deklarację Teherańską ${ }^{8}$. Porozumienie przewidywało pełną współpracę Iranu z MAEA, wstrzymanie przez ten kraj wzbogacania uranu ,na okres przejściowy" i zaniechanie budowy instalacji do tego procesu oraz podpisanie dodatkowego protokołu do NPT. Protokół ten (podpisany przez Iran 18 grudnia 2003 r.) dawał MAEA prawo do niezapowiedzianych i nieograniczonych inspekcji w irańskich obiektach nuklearnych. W zamian za to EU 3 oferowała Irańczykom pomoc w pokojowym wykorzystaniu energii atomowej.

Tymczasem w 2004 r. okazało się, że państwa pragnące nielegalnie pozyskać broń atomową (Irak, Iran, Korea Północna, Libia, Syria) w odpowiedzi na restrykcje ze strony społeczności międzynarodowej zawiązały własną nieformalną współpracę. Już od końca lat 80. eksperci nuklearni z najmłodszego mocarstwa nuklearnego - Pakistanu, nielegalnie handlowali z tymi państwami sprzętem i technologiami. Pogłębiło to podejrzenia państw zachodnich co do Iranu i spowodowało, że w kolejnym raporcie z 1 czerwca 2004 r. MAEA zarzuciła temu krajowi potajemną realizację wojskowego programu nuklearnego (Denza, 2005, s. 289-311) . $^{9}$ Odpowiedzią Teheranu 31 lipca była deklaracja wznowienia wzbogacania uranu oraz budowy instalacji temu służących, a 24 października Iran odrzucił ofertę EU 3, proponującą zaniechanie samodzielnego wzbogacania uranu i badań nuklearnych w zamian za udostępnienie mu nowoczesnych, pokojowych technologii nuklearnych, dostaw paliwa dla elektrowni atomowych oraz pomocy w budowie tzw. reaktora lekkiej wody (nie nadającego się do wytwarzania ładunku do głowic bojowych) - i zapowiedział dalsze wzbogacanie uranu.

Jednak 15 listopada 2004 r. państwa EU 3 zawarly z Iranem porozumienie (tzw. ,paryskie"), w którym Teheran zgadzal się na wstrzymanie wzbogacania uranu w zamian za koncesje handlowe, polityczne i z zakresu cywilnej energetyki jądrowej. MAEA zaakceptowała ten układ i uznała decyzję Iranu za „,dobrowolny, niewiążący środek budowy zaufania" (Posch, 2006, s. 103-106). Z kolei 13 grudnia 2004 r. rozpoczęły się rozmowy Iranu z EU 3 na temat całkowitego i stałego zawieszenia wzbogacania uranu w zamian za przywileje ekonomiczne. Politykę tę wsparły Stany Zjednoczone - na szczycie UE-USA w Brukseli 22 lutego 2005 r., postanowiono, że jeśli Teheran rzetelnie wykona porozumienie, USA dołączą do unijnej oferty własne propozycje gospodarcze (umożliwienie Iranowi zakupu wysokich technologii cywilnych i wstąpienia do WTO $)^{10}$. Natomiast jeśli Iran wznowi wzbogacanie uranu i naruszy Porozumienie Paryskie, to EU 3 poprze amerykański wniosek o oddanie sprawy do RB ONZ.

8 Statement by the Iranian Government and Visiting EU Foreign Ministers, 21 October 2003, http://www.iaea.org/newscenter/focus/iaeairan/statement_iran21102003.shtml, 2012.10.25.

9 Teheran oskarżano m.in. o ukrywanie części dokumentacji programu, niedopuszczanie inspektorów MAEA do niektórych instalacji, posiadanie niezadeklarowanych zasobów wzbogaconego ura$\mathrm{nu}$ - zob. IAEA, BoG, Implementation of the NPT Safeguards Agreement in the Islamic Republic of Iran; Report by the Director General, GOV/2004/34, Date: 1 June 2004, Derestricted 18 June 2004.

10 Wniosek Iranu wplyną jeszcze w 1996 r., a dopiero 26 maja 2005 r. zaczęla prace Grupa Robocza WTO zajmująca się przyjęciem tego kraju. 
Szczyt RE w Brukseli 16-17 czerwca 2005 r. przywoływał ten właśnie sukces w rokowaniach (pkt 55-56) ${ }^{11}$ : „RE z zadowoleniem wita wznowienie negocjacji z Iranem w sprawie umowy o handlu i współpracy oraz porozumienia politycznego, co stało się możliwe po podpisaniu i skutecznym wdrożeniu porozumienia paryskiego w listopadzie 2004 r. [... $]^{12}$. Potwierdza gotowość UE do wypracowania możliwości dalszego rozwoju współpracy politycznej i gospodarczej z Iranem w następstwie działań podjętych przez to państwo w celu rozwiazzania innych kwestii budzących zaniepokojenie UE $[\ldots]^{\prime \prime 13}$. Była to więc oferta wielopłaszczyznowej współpracy, ale kwestii budzących zaniepokojenie było znacznie więcej: Iran budował pozycję regionalnego mocarstwa na Bliskim i Środkowym Wschodzie (Halliday, 2006, s. 59-62).

Jednak już wkrótce irańska polityka miała się bardzo usztywnić: zarówno wybory parlamentarne z 2004 r., jak i prezydenckie z 2005 r. przyniosły sukces konserwatystom i radykałom religijnym - prezydentem kraju został ich lider Mahmud Ahmadineżad. Spowodowało to intensyfikację irańskich prac nad potencjałem nuklearnym i usztywnienie stanowiska wobec zagranicy (Farhi, 2013, s. 29-38; Kapiszewski, 2006, s. 17-21). „Konserwatywna część irańskiej sceny politycznej rozpoczęła kampanię mającą na celu odrzucenie dotychczasowych porozumień i kontynuowanie programu nuklearnego bez współpracy z UE [...]. Mając poparcie takich krajów jak Chiny i Rosja, Iran stał na stanowisku swojego niezbywalnego prawa do posiadania pokojowego programu atomowego i jednoznacznie odrzucał oskarżenia o prowadzenie badań w celu uzyskania broni atomowej" (Ćwioro 2009, s. 113).

Już 15 sierpnia $2005 \mathrm{r}$. Iran poinformował MAEA, że kończy moratorium przyjęte w „porozumieniu paryskim” i wznawia przetwarzanie uranu. Odrzucił też propozycję podarowania przez UE reaktora jądrowego lekkiej wody, dla celów cywilnych. Dyrektor generalny MAEA, El Baradei, 2 września zarzucił Iranowi, że „nie pozwala agencji na wyjaśnienie kwestii niezałatwionych po 2,5 roku intensywnych inspekcji i badań" (IAEA, 2005), a 24 września zarząd MAEA stwierdził w rezolucji, że Iran nie przestrzega traktatu NPT i że uzasadnia to oddanie sprawy do RB ONZ.

Reakcja UE była symptomatyczna: trudno było nadal twierdzić, że współpraca z Iranem dobrze się układa, ale też trudno było zdezawuować własne wysiłki z ostatnich lat. Na szczycie RE 15-16 grudnia 2005 r. przyjęto więc „Oświadczenie Rady Europejskiej" (RE, 2005b), które dotyczyło formalnie całego Bliskiego Wschodu, aczkolwiek zdominowane było właśnie przez problem Iranu (pkt 3-5) ${ }^{14}$, „RE surowo po-

11 RE w Brukseli, 16-17 czerwca 2005 r., Konkluzje Prezydencji, RUE, Bruksela, 15 lipca 2005 r., 10255/1/05 REV 1.

12 Pominięty fragment zawiera zdanie: „Podkreśla znaczenie, jakie przywiązuje do równego traktowania w stosunkach handlowych wszystkich Państw Członkowskich" - był to komentarz do faktu, iż Iran (największa gospodarka nienależąca obecnie do WTO, a posiadająca jedynie status obserwatora) samowolnie różnicuje warunki handlu z poszczególnymi państwami UE, wykorzystując animozje pomiędzy nimi.

${ }_{13} \mathrm{~W}$ pominiętym fragmencie wymieniono owe inne kwestie, budzace zaniepokojenie UE: zwalczanie terroryzmu, prawa człowieka, stosunek Iranu do procesu pokojowego na Bliskim Wschodzie.

${ }^{14}$ Fragmenty tego oświadczenia otrzymaly śródtytuly: Iran; Irak; Liban; Proces pokojowy na Bliskim Wschodzie; Stabilność regionalna; Reformy polityczne, społeczne i gospodarcze; Proces barceloński; Libia. W ten sposób można było stworzyć wrażenie, że to nie sytuacja w Iranie jest najważniejszym problemem, do którego musi odnieść się UE. W myśl tego oświadczenia UE ,po- 
tępia głoszone przez prezydenta Ahmadineżada wezwanie do zniszczenia Izraela i zanegowanie przez niego istnienia Holocaustu [...]. RE przypomina, że w listopadzie bieżącego roku ZO ONZ przyjęło w drodze consensusu, włącznie z Iranem, rezolucje, która «odrzuca jakiekolwiek pełne lub częściowe zaprzeczenie Holocaustu jako wydarzenia historycznego» wzywając wszystkie Państwa Członkowskie do przekazywania swoim obywatelom wiedzy na temat Holocaustu [...]" (UN, 2005).

„RE jest głęboko zaniepokojona faktem, że Iran nie zdołał przekonać o całkowicie pokojowym charakterze swego programu jądrowego [...]. Chociaż UE nie ustaje w pracach nad rozwiązaniem dyplomatycznym, dostępne możliwości mogą się wkrótce wyczerpać, RE nalega więc, aby Iran zareagował w sposób konstruktywny, m.in. [...] powstrzymując się od dalszych jednostronnych ruchów, które mogłyby zaostrzyć sytuację $[\ldots]$.

RE ponownie wyraża głębokie zaniepokojenie brakiem poszanowania praw człowieka oraz podstawowych swobód politycznych w Iranie i wzywa Iran do wykazania poszanowania dla tych zasad poprzez podjęcie konkretnych kroków, takich jak ostateczne uwolnienie [...] więźniów sumienia. W duchu solidarności UE Rada wzywa Iran do zniesienia wszystkich ograniczeń dyskryminujących wobec poszczególnych Państw Członkowskich".

Oświadczenie to miało bardzo znamienną konstrukcję. W pierwszej jego części UE krytykuje wypowiedzi prezydenta Iranu, wzywające do zniszczenia Izraela i negujące Holokaust, przy czym nadaje tym dwu wątkom podobne znaczenie. W świetle prawa międzynarodowego zakazującego tak agresji, jak i grożenia nia, pierwszy typ wypowiedzi jest bez porównania ważniejszy - publiczna deklaracja głowy państwa uznającej jakiś kraj za niegodzien istnienia, jest faktem tworzącym politykę międzynarodową ${ }^{15}$. Tymczasem UE jako pierwszy powód potępienia Iranu podawała wypowiedzi (bez wątpienia haniebne) negujące masowe mordy dokonywane na Żydach przez Niemców podczas II wojny światowej ${ }^{16}$.

W drugiej części przytoczonego fragmentu UE odnosiła się do meritum: kontynuowanego przez Iran programu atomowego, który wykraczać mógł poza cele cywilne. $Z$ tekstu wynikało jednak, że głównym problemem był nie tyle wojskowy charakter tego programu i wola Iranu, aby go zrealizować bez względu na opinię świata - co brak przejrzystości działań Irańczyków i ich nieumiejętność przekonania do swoich racji międzynarodowej opinii publicznej. UE przyjęła w tym fragmencie milczące założenie, że Irańczycy chcą porozumienia i kompromisu, ale z uwagi na ich niezręczność i „obiektywne trudności”, porozumienie się oddala. Nie było to ostrzeżenie, więc nie

twierdza, że nadal udziela wsparcia” Irakowi (pkt 6 „oświadczenia”); „zapewnia o swoim poparciu” dla Libanu (pkt 8) czy „odnotowuje postęp” w relacjach z Libią (pkt 18).

${ }_{15}$ Może np. skłaniać władze tak opisywanego kraju do podejmowania działań podnoszących jego bezpieczeństwo - dozbrajania się, zawierania nowych sojuszy, w ostateczności - do ataku uprzedzającego (jak w wypadku Izraela właśnie w 1967 r.)

16 Wypowiedzi takie mogą świadczyć o zacietrzewieniu Ahmadineżada, bądź o jego nikłej wiedzy historycznej, bez wątpienia psują kulturę dyplomacji i niszczą zaufanie międzynarodowe - ale ich praktyczne znaczenie dla pokoju i bezpieczeństwa międzynarodowego jest wyraźnie mniejsze niż deklarowana groźba zniszczenia innego państwa, życzenie mu upadku, czy deklarowanie poparcia dla działań szkodliwych dla tego państwa podejmowanych przez innych aktorów. 
zawierało żadnych sankcji - jedynie „głębokie zaniepokojenie” Unii i jej obawę, że dostępne możliwości rozwiązań dyplomatycznych „mogą się wkrótce” wyczerpać (Posch, 2006, s. 106-111) ${ }^{17}$.

Jedynym, bardzo zawoalowanym, ostrzeżeniem było zawarcie $w$ ostatnim fragmencie oświadczenia, iż długofalowe stosunki UE-Iran mogą zostać wzmocnione bądź osłabnąć. W jednym zdaniu UE mieszała żądania dotyczące wewnętrznej polityki Iranu z tymi, dotyczącymi równego traktowania przez Iran unijnych państw członkowskich.

\section{Przyspieszenie prac Iranu}

Dnia 25 grudnia 2005 r. Iran odrzucił kolejną ofertę UE - otrzymywania wzbogaconego uranu z Rosji (zamiast wytwarzania własnego), a 10 stycznia 2006 r. nakazał inspektorom MAEA usunięcie plomb w zakładzie wzbogacania uranu w Natanz, wznawiając tym samym prace nad paliwem jądrowym i ostatecznie zrywając moratorium z 2004 r. Na fali powszechnego potępienia Iranu, 4 lutego 2006 r. zarząd MAEA wezwał RB ONZ do uznania irańskiego programu nuklearnego za zagrożenie dla pokoju międzynarodowego. Inicjatywę tą poparły zarówno USA, grupa EU 3, jak i Rosja oraz Chiny, a w konsekwencji grupa negocjująca $z$ Iranem zmieniła się $w$ formułę nazywaną „E3+3” (Francja, Niemcy, Wielka Brytania + Chiny, Rosja, USA) bądź „P5+1” (stali członkowie RB ONZ + Niemcy). Z kolei 29 marca $2006 \mathrm{r}$. RB ONZ wezwała Iran do zakończenia w ciągu 30 dni wzbogacania uranu pod groźbą izolacji międzynarodowej, ale już 11 kwietnia prezydent Ahmadineżad ogłosił, że jego kraj opanował cyk1 produkcji paliwa jądrowego i wzbogacenia uranu dla elektrowni atomowych - tym samym wchodząc do „klubu atomowego”. Szacunki zachodnie wskazywały na nieodległy termin uzyskania broni atomowej przez ten kraj, co skłaniało do rozpatrywania możliwości zbrojnego ataku na jego instalacje nuklearne przez USA lub Izrael (Ehteshami, 2006, s. 82-85).

Dnia 1 czerwca 2006 r. grupa E3+3 uzgodniła kolejny pakiet propozycji, który szef unijnej dyplomacji J. Solana przedstawił Iranowi 5 dni później. W zamian za zaprzestanie wzbogacania uranu i powrót do negocjacji zaoferowano Irańczykom hojną pomoc gospodarczą (m.in. w budowie reaktora na lekką wodę), zniesienie sankcji (m.in. w zakresie zakupu nowych samolotów pasażerskich i części do nich) oraz polityczną (poparcie starań Iranu o członkostwo w WTO). USA ze swej strony zaoferowały ograniczenie własnych sankcji gospodarczych i podjęcie bezpośrednich rozmów z Iranem. Propozycja nie wykluczała możliwości wzbogacania przez Iran uranu dla celów badawczych.

RE w swoich konkluzjach z 15-16 czerwca 2006 r., zamieściła ,Załącznik III - Deklarację w sprawie Iranu”, komentując te wydarzenia (RE, 2006): „RE ponowiła swoje zobowiązanie do osiagnięcia dyplomatycznego rozwiązania [...] programu jądrowego Iranu, podkreślając jednocześnie prawo Iranu do pokojowego wykorzystania energii

${ }_{17}$ Jeśli odrzucić taką hipoteze, to pozostaje chyba uznać, że UE w ogóle nie rozumiala ani nie starała się zrozumieć irańskiej polityki i aspiracji. 
jądrowej zgodnie z Układem NPT. [...] RE udziela pełnego poparcia wyważonemu podejściu zawartemu w inicjatywie wiedeńskiej i zachęca Iran do skorzystania z przedstawionej mu pozytywnej propozycji. [...] RE namawia Iran do szybkiej pozytywnej reakcji na tę daleko idącą inicjatywę oraz do stworzenia warunków umożliwiających wznowienie negocjacji".

Był to więc pozytywny komentarz do inicjatywy, która stawała się wspólnym działaniem całej społeczności świata. Zarazem UE akceptowała, że nie ona sama jako organizacja, lecz trzy jej państwa członkowskie odgrywać będą w tym procesie główną rolę.

Iran nie udzielił odpowiedzi, co skutkowało przyjęciem 31 lipca przez RB ONZ rezolucji nr 1696 wzywającej Teheran do „pełnego i trwałego" wstrzymania działań związanych ze wzbogacaniem uranu (także dla celów naukowo-badawczych) do 31 sierpnia 2006 r., pod groźbą nałożenia sankcji dyplomatycznych i gospodarczych (UN, 2006). Odpowiedź Iranu z 22 sierpnia była odmowna (Halliday, 2006, s. 70-71) ${ }^{18}$. Ponieważ dodatkowo 31 sierpnia raport MAEA potwierdził, iż Iran nie zaprzestał wzbogacania uranu i narusza zapisy NPT (IAEA, 2006), 6 października w Londynie szefowie dyplomacji E3 +3 zapowiedzieli wprowadzenie sankcji wobec Iranu (Ćwioro, 2009, s. 116-117) ${ }^{19}$.

Kolejny szczyt RE w dniach 14-15 grudnia 2006 r. również zamieścił w swoich konkluzjach „Deklarację w sprawie Iranu”, stwierdzającą (RE, 2006b): „RE wyraża zaniepokojenie negatywnym wpływem prowadzonej przez Iran polityki na stabilność i bezpieczeństwo na Bliskim Wschodzie. RE podkreśla, że Iran musi odgrywać odpowiedzialną rolę $\mathrm{w}$ regionie. RE wyraża w szczególności ubolewanie z powodu niepodjęcia przez Iran kroków wymaganych przez Radę Gubernatorów MAEA oraz RB ONZ i stwierdza, że z powyższego mogą wyniknąć wyłącznie negatywne konsekwencje dla stosunków między UE a Iranem [...]"20.

W tej deklaracji UE odwołała się do „odpowiedzialności” jako kategorii w stosunkach międzynarodowych, której nie wypełniał, chociaż mógł i powinien - Iran. W tym kontekście działaniem destabilizującym był brak współpracy Iranu z organizacjami międzynarodowymi, odpowiedzialnymi za kontrolę nad światowym bezpieczeństwem atomowym.

„W związku z tym, że Iran nie podjął żadnych działań, aby wypełnić owe zobowiązania, RE wspiera prace na forum RB mające na celu przyjęcie środków na podstawie art. 41 rozdz. VII Karty NZ. RE wyraża głębokie zaniepokojenie ostatnimi oświadczeniami rządu irańskiego dotyczącymi UE i pojedynczych państw członkow-

$18 \mathrm{http}: / /$ www.stosunkimiedzynarodowe.info/kraj,Iran,problemy,Program_nuklearny, 3.10.2012. W międzyczasie w dniach 12 lipca-14 sierpnia 2006 r. doszło do wojny armii Izraela z działającymi w południowym Libanie i zaopatrywanymi przez Iran bojówkami radykałów islamskich Hezbollach. Starcie to, które nie zakończylo się przekonującym sukcesem Izraela i udowodniło duży potencjał islamistów, pokazalo, jak wzrosła rola Iranu na Bliskim Wschodzie.

${ }_{19} \mathrm{~W}$ celu uzyskania rosyjskiego poparcia, państwa E3 zaproponowały wylączenie spod sankcji inwestycji irańsko-rosyjskich (reaktora w Buszehr). Rosja uznala jednak te wyłączenia za niewystarczające, jednocześnie podkreślając, że jej wspólpraca nuklearna z Iranem ma charakter pokojowy.

20 Owe negatywne konsekwencje nie zostaly jednak sprecyzowane, mimo zapowiedzianych ponad dwa miesiące wcześniej sankcji (które uchwalono tydzień po szczycie RE). 
skich, jak również jego groźbami wobec Izraela i dalszym pogorszeniem się sytuacji jego obywateli $w$ dziedzinie praw człowieka i swobód politycznych ${ }^{21}$. UE potępia jakiekolwiek zaprzeczanie - w całości lub w części - istnieniu Holokaustu jako faktu historycznego i w związku z tym zdecydowanie odrzuca podstawowe założenia i cele konferencji na temat Holokaustu zorganizowanej przez władze Iranu"22.

\section{Sankcje międzynarodowe}

Ostatecznie 23 grudnia 2006 r. RB ONZ jednomyślnie uchwaliła rezolucję nr 1737, po raz pierwszy nakładającą na Iran sankcje za prowadzenie programu atomowego (UN, 2006b). Sankcje obejmowały zakaz sprzedaży lub transferu do Iranu technologii nuklearnych oraz zamrożenie aktywów 12 osób i 10 instytucji związanych z tym programem. RB ONZ zapowiedziała w dodatku podjęcie kolejnych decyzji, jeśli Teheran nie wykona jej zaleceń w ciągu 60 dni. W ciagu tego czasu Dyrektor Generalny MAEA miał opracować raport o działaniach Iranu - dokument ten powstał 22 lutego $2007 \mathrm{r}$. (IAEA, 2007a) i zarzucal Iranowi kontynuowanie wzbogacania uranu. Na tej podstawie miesiąc później, 24 marca RB ONZ jednomyślnie uchwaliła rezolucję nr 1747, zacieśniającą sankcje poprzez wprowadzenie zakazu handlu i dostaw broni do i z Iranu, zamrożenie aktywów 15 obywateli i 13 instytucji tego państwa związanych z programem nuklearnym oraz zakaz udzielania Iranowi wsparcia finansowego przez wszystkie państwa i instytucje finansowe (UN, 2007).

Sankcje te nie powstrzymały Irańczyków: 9 kwietnia 2007 r. M. Ahmadineżad ogłosił, że Iran opanował już zdolność wzbogacania uranu na skalę przemysłową, a 23 maja MAEA stwierdziła, że możliwości Iranu w tym zakresie faktycznie wzrosły (IAEA, 2007b). Mimo że Iran wzbogacał uran, 21 sierpnia MAEA ustaliła z nim harmonogram wyjaśnienia wszelkich aspektów jego programu nuklearnego, a 30 sierpnia pozytywnie zaopiniowała warunki współpracy ${ }^{23}$.

Tymczasem prezydent Ahmadineżad ogłosił 2 września 2007 r., że Iran posiada już ponad 3 tys. wirówek do wzbogacania uranu (co wystarczałoby do zbudowania bomby atomowej w ciagu jednego roku), a 25 września - że spór o irański program nuklearny

${ }^{21}$ Ten katalog zarzutów byl formulowany już wcześniej i - jak wcześniej - jest dość chaotyczny. Każdy z nich byłby dość poważny i zasługiwałby na rozwinięcie, umieszczenie ich $w$ jednym zdaniu sprawia wrażenie wręcz odbierania im powagi, traktowania wylącznie pro forma.

22 Dość nieszczęśliwie sformułowano to zdanie - $\mathrm{z}$ potępienia negacji Holokaustu przeformułowano je w zaprzeczenie swobody badan naukowych. Skoro skrytykowano „założenia i cele", a nie „efekty” irańskiej konferencji poświęconej tej tragedii, to stanowisko UE może być odbierane jako antynaukowe (negacjoniści organizujący swoje spotkanie przedstawiać mogą się jako obrońcy wolności słowa). W dodatku zajmowanie się takim wydarzeniem przez szczyt szefów państw i rządów UE paradoksalnie podnosi jego znaczenie - czy tak szacowne gremium musi enumeratywnie wskazywać, które ze spotkań negacjonistów zasługują na szczególne potępienie?

${ }^{23}$ The work plan is a significant step forward (pkt 23 Raportu) - IAEA, BoG, Implementation of the NPT Safeguards Agreement in the Islamic Republic of Iran, Report by the Director General. GOV/2007/48, Date: 30 August 2007, Derestricted 12 September 2007; zob.też zalącznik do raportu Understandings of the Islamic Republic of Iran and the IAEA on the Modalities of Resolution of the Outstanding Issues, Tehran - 21 August 2007. 
jest „zamknięty”, a kraj ten zignoruje kolejne rezolucje RB ONZ. MAEA, szukając porozumienia, w kolejnym raporcie 15 listopada stwierdziła, że Teheran wyjaśnił wcześniejsze swoje poczynania, ale od początku 2006 r. nie dostarczyl informacji o swoich aktualnych działaniach (IAEA, 2007d).

Reakcją UE było „ubolewanie” wyrażone na szczycie RE, 14 grudnia 2007 r. (RE, 2007) (konkluzje, pkt 82-86): „RE potwierdza, że jest poważnie zaniepokojona irańskim programem nuklearnym i podkreśla, że zdobycie broni jądrowej przez Iran jest nie do przyjęcia. W związku z tym ubolewa, że Iran nie wypełnił jeszcze zobowiązań międzynarodowych [...], dotyczących zawieszenia wszelkich działań związanych ze wzbogacaniem i ponownym przetwarzaniem uranu, co ma odbudować zaufanie do w pełni pokojowej natury jego programu” ${ }^{24}$. „RE wzywa Iran do przekazania MAEA wyczerpujących, jasnych i wiarygodnych odpowiedzi, by rozwiązać wszystkie kwestie dotyczące działań nuklearnych Iranu [...]. RE potwierdza pełne i zdecydowane poparcie dla wysiłków zmierzających do wynegocjowania długoterminowego rozwiązania irańskiej kwestii nuklearnej i podkreśla, że propozycje przedstawione 6 czerwca $2006 \mathrm{r}$. przez WP PZB dałyby Iranowi wszystko, czego potrzebuje do rozwinięcia cywilnego przemysłu jądrowego, wychodząc jednocześnie naprzeciw oczekiwaniom społeczności międzynarodowej".

Ta deklaracja definiowała sytuację na nowo: UE dostrzegała irańskie aspiracje do posiadania broni atomowej i kategorycznie się im sprzeciwiała - akceptując rozwijanie przez ten kraj cywilnego potencjału jądrowego. Warto zauważyć, że przywracano znaczenie WP PZB, ściśle kooperującemu z MAEA w próbach wynegocjowania kompromisu. O ile Unia podtrzymała własną ofertę z 6 czerwca 2006 r., o tyle nie formułowała żadnych własnych sankcji - deklarowała jedynie wsparcie dla aktywności RB ONZ.

W kolejnym raporcie z 22 lutego 2008 r. MAEA stwierdziła, że Iran wyjaśnił większość kwestii związanych z wcześniejszymi fazami programu nuklearnego, ale prowadzi budzące obawy prace nad technologią rakietową i zaawansowanymi materiałami wybuchowymi, co podważa przekonanie o pokojowej naturze jego działań (IAEA, 2008a). W następstwie RB ONZ przyjęła 3 marca 2008 r. rezolucję $\mathrm{nr} 1803$ nakładającą na Iran trzecią serię sankcji, rozszerzającą listy osób objętych zakazem wjazdu do UE i firm, którym na terenie UE zamrożono aktywa oraz wprowadzającą zakaz eksportu do Iranu towarów podwójnego zastosowania (UN, 2008a). Rezolucja ta oprócz nowych sankcji zachęcała jednocześnie Iran do wznowienia dialogu z grupą E3+3 i do przekonania jej o pokojowym charakterze irańskiego programu nuklearnego. Przyjęciu rezolucji towarzyszyło oświadczenie państw E3+3 o ich woli prowadzenia z Teheranem negocjacji i osiagnięcia z nim trwałego porozumienia. To „dwutorowe podejście" miało zachęcić Iran do wznowienia wspólpracy z MAEA.

${ }^{24}$ Ten akapit zawiera wewnętrzną sprzeczność: założenie, że Iranowi zależy na zdobyciu broni jądrowej (i że jest to dla reszty świata nie do zaakceptowania) oznacza, że bojkotowanie przez ten kraj oczekiwań ONZ i MAEA jest świadome. W związku z tym „wyrażanie ubolewania”, że Iran ,jeszcze" nie spełnił zobowiązań międzynarodowych i nie odbudowal zaufania do swojego programu - to hipokryzja. Przecież jeśli Iran buduje potencjal wojskowy, to „odzyskanie zaufania” za cenę wyhamowania tego programu nie jest dla niego żadną alternatywą. 
Kolejny raport MAEA został wydany 26 maja 2008 r. i zarzucał Iranowi, że wciąż ukrywa on kluczowe dokumenty dotyczące programu nuklearnego, ale też zaznaczał, że nie ma dowodów na militarny charakter tego programu (IAEA, 2008b). W imieniu UE 14 czerwca 2008 r. WP PZB przekazał Teheranowi ofertę grupy E3+3 zawierającą szeroki pakiet zachęt (m.in. liberalizacji handlu i rozwoju cywilnej współpracy nuklearnej) w zamian za wstrzymanie wzbogacania uranu. Władze irańskie od razu odrzucily tą ofertę, a reakcją UE było zamrożenie 23 czerwca 2008 r. aktywów największego banku Iranu - Banku Melli.

Nieudane rokowania zachęciły 6 sierpnia 2008 r. pięciu członków grupy E3+3 do wnioskowania o nałożenie na Iran czwartej serii sankcji przez RB ONZ, jednak Rosja oświadczyła, że nie poprze takiej decyzji ${ }^{25}$. Raport MAEA z 15 września stwierdzal, że Iran blokuje próby zbadania militarnego wymiaru swojego programu (IAEA, 2008c), a 27 września RB ONZ uchwaliła rezolucję nr 1835, ponownie wzywającą to państwo do wstrzymania wzbogacania uranu (ale bez nakładania żadnych nowych sankcji) (UN, 2008b). Kolejny raport MAEA z 19 listopada stwierdzał, że Iran zadeklarował wprawdzie i pozwolił zweryfikować ilość posiadanego nisko wzbogaconego uranu (miało to być $630 \mathrm{~kg}$, co według niektórych analiz wystarczałoby już do zbudowania pojedynczej bomby atomowej), ale nie pozwolił badać nowych wirówek do jego wzbogacania ani innych instalacji; nie wypełnia też pozostałych postanowień MAEA (IAEA, 2008d).

Sytuację w regionie na przełomie 2008 i 2009 zaostrzył kolejny konflikt izraelsko-palestyński: w odpowiedzi na ostrzał prowadzony ze Strefy Gazy przez bojówki Hamas, armia Izraela w dniach 27 grudnia-19 stycznia pacyfikowała Gazę.

W raporcie MAEA z 19 lutego 2009 r. wskazywano, że Iran nie współpracuje rzetelnie $w$ badaniu jego potencjału nuklearnego. $Z$ drugiej jednak strony nie można było mu zarzucić całkowitego braku współdziałania: Iran udzielał Agencji częściowych odpowiedzi, kwestionował jej obliczenia, jak np. szacunki wzrostu jego zasobów nisko wzbogaconego uranu: z $1010 \mathrm{~kg}$ w lutym $2009 \mathrm{r}$. do $1300 \mathrm{~kg}$ w czerwcu $2009 \mathrm{r}$. (IAEA, 2009a). W kolejnym raporcie MAEA z 5 czerwca 2009 r. podkreślano te rozbieżności, wskazując że dane szacunkowe mogą być niedokładne, ale mają tendencję jednoznacznie rosnącą - np. liczba irańskich wirówek miała się zwiększyć z 5 tys. jesienią $2008 \mathrm{r}$. do 7 tys. wiosną 2009 r. (IAEA, 2009b).

W pierwszej połowie 2009 r. negocjacje w sprawie irańskiego programu nuklearnego znalazły się na nieco dalszym planie, ponieważ społeczność międzynarodowa liczyła, że w wyborach prezydenckich 12 czerwca M. Ahmanineżad nie uzyska reelekcji. Nadzieje te okazały się jednak płonne: mimo oskarżeń o fałszerstwa wyborcze, polityk ten utrzymał się u władzy (Farhi, 2013, s. 23-26).

RE, obradująca w dniach 18-19 czerwca 2009 r. w Brukseli, w dołączonym do konkluzji: „Oświadczeniu w Sprawie Iranu”, również skupiła się na kwestii wyborów prezydenckich (RE, 2009a): „RE [...] podkreśliła, że wynik irańskich wyborów powinien odzwierciedlać aspiracje i preferencje Irańczyków. RE powtórzyła, że kwestią, którą władze irańskie powinny się zająć, są wątpliwości co do przebiegu wyborów. [...] RE zaapelowała do władz irańskich o to, by zapewniły wszystkim Irańczykom prawo do

25 Asertywność Rosji została podkreślona w tym samym sierpniu 2008 r. przez konflikt z Gruzją - Rosjanie skutecznie wsparli separatystów, pragnących oderwać od Gruzji dwie prowincje. 
pokojowego gromadzenia się i wyrażania opinii. [...] RE podkreśliła także, że ważne jest, by Iran prowadził dialog ze społecznością międzynarodową co do wszystkich niepokojących kwestii - zwłaszcza co do irańskiego programu jądrowego - w duchu wzajemnego szacunku i z pełnym poszanowaniem swoich międzynarodowych zobowiązań".

Stanowisko UE było dość wyważone i ostrożne - wiadomo, że życzyła Ahmadineżadowi porażki, co mogłoby uczynić politykę Iranu bardziej prozachodnią i przewidywalną (Kuźniar 2011, s. 443-444) ${ }^{26}$. Kwestia irańskiego programu nuklearnego została w tym dokumencie zaledwie wzmiankowana.

Wkrótce po wyborach społeczność międzynarodowa zaczęła wzywać Iran do wznowienia negocjacji nad programem nuklearnym pod groźbą zacieśnienia sankcji. Kolejny raport MAEA z 28 sierpnia 2009 r. powtarzał wcześniejsze zarzuty o kontynuowanie wzbogacania uranu i brak współpracy, ale formułował pod adresem Iranu nową oferte (IAEA, 2009c). Jeśli do końca roku kraj ten oddałby $80 \%$ posiadanego uranu pod kontrolę międzynarodowa, to otrzymałby w zamian paliwo atomowe do posiadanego małego reaktora badawczego w Teheranie (a także izotopy do leczenia nowotworów) ${ }^{27}$. Iran przedstawił własną kontrpropozycję - przekazywałby uran etapami, zachowując sobie przez cały czas ilość surowca potrzebną do wytwarzania glowic bojowych. Tymczasem jednak przywódcy USA, Francji i Wielkiej Brytanii powiadomili 25 września o istnieniu pod miastem Qom tajnego zakładu wzbogacania uranu. Zarzucili Iranowi wprowadzanie w błąd MAEA i zażądali natychmiastowych wyjaśnień w sprawie jego programu atomowego ${ }^{28}$. Oskarżenia te potwierdziła MAEA w kolejnym raporcie z 16 listopada, stwierdzając, że ukrywanie przez Iran instalacji nuklearnych podważa jego wiarygodność i wzywając do natychmiastowego wstrzymania dalszych prac (IAEA, 2009d). W odpowiedzi rząd irański 29 listopada zapowiedział budowę kolejnych 10 zakładów wzbogacania uranu.

\section{Usztywnienie polityki UE}

Pogarszanie się relacji Iranu z Zachodem skłoniło również UE do zmiany stanowiska. Zbiegło się to z wejściem w życie Traktatu lizbońskiego, poważnie modyfikującego zasady funkcjonowania UE - przy tej okazji zmieniono nazwę instytucji odpowiedzialnej za unijną politykę zagraniczną. Obecnie jest to Wysoki Przedstawiciel

26 Symptomatyczne było, że Irańczycy protestujący w Teheranie przeciwko fałszerstwom wyborczym nieśli transparenty z hasłem Where is my vote?, tak jakby opinia anglojęzycznych mediów i odbiorców była dla nich ważniejsza niż przekonanie większości własnych rodaków.

27 Jak szacowano Iran posiadal ok. 1,5 tony uranu i przekazujac 1,2 tony zostawilby sobie zbyt mało surowca, aby skonstruować choćby jedna głowicę nuklearną. Zaproponowano przechowanie tego surowca w Rosji, jako najbardziej proirańskim państwie grupy E3 +3 .

${ }_{28}$ O ile nie dziwi nieobecność w tej trójce Rosji czy Chin, o tyle na uwagę zasługuje brak w niej Niemiec: są one jedynym państwem w grupie E3+3 nienależącym do RB ONZ i nieposiadającym wojskowego potencjału nuklearnego. Z punktu widzenia Francji i Wielkiej Brytanii prozachodniość Niemiec, ich czlonkostwo w UE i NATO - nie byly jednak wystarczająco ważnymi argumentami, aby dzielić się z Berlinem danymi wywiadowczymi i dopuszczać do wspólnej inicjatywy „zachodnich mocarstw nuklearnych", co przecież wzmocniłoby ja. 
do spraw Zagranicznych i Polityki Bezpieczeństwa (WP SZiPB), a stanowisko to objęła pod koniec 2009 r. Brytyjka Catherine Aston. Na pierwszym szczycie RE po wejściu w życie Traktatu lizbońskiego 10-11 grudnia 2009 r. w Brukseli, przyjęto „Oświadczenie w sprawie Iranu”, w którym stwierdzono (RE, 2009b): „RE podkreśla, że od 2004 r. UE dąży do wypracowania dyplomatycznego rozwiązania kwestii irańskiego programu jądrowego. RE wyraża poważne zaniepokojenie faktem, że Iran do tej pory nie podją żadnych kroków, by odbudować wiarę społeczności międzynarodowej w wyłącznie pokojowy charakter realizowanego przez ten kraj programu jądrowego [...]. RE ponownie wzywa Iran, by całkowicie i bezzwłocznie wypełnił swoje zobowiązania wynikające $\mathrm{z}$ właściwych rezolucji RB ONZ oraz MAEA, a zwłaszcza by spełnił wymogi określone w rezolucji Rady Gubernatorów MAEA z 27 listopada $2009 \mathrm{r}^{29}$ [...] RE z wielkim zaniepokojeniem odnotowuje fakt, że Iran nie skorzystał $\mathrm{Z}$ wielokrotnie ponawianych propozycji Chin, Francji, Niemiec, Rosji, Stanów Zjednoczonych, Zjednoczonego Królestwa oraz wysokiego przedstawiciela UE Javiera Solany, podjęcia dalszych dyskusji na temat irańskiego programu jądrowego i innych kwestii będących przedmiotem wspólnego zainteresowania [...]. W związku z powyższym UE jest wciąż gotowa podjąć rozmowy z Iranem, tak aby znaleźć rozwiązanie tej kwestii w drodze negocjacji, gdyby Iran podjął konkretne decyzje w tym kierunku. [...] UE udzieliłaby poparcia działaniom RB ONZ, jeżeli Iran będzie w dalszym ciagu odmawiał współpracy ze społecznością międzynarodową w zakresie swojego programu jądrowego [...] RE ponownie stwierdza, że jest głęboko zaniepokojona powtarzającymi się wciąż przypadkami naruszania praw człowieka w Iranie $[\ldots] "$.

UE podsumowała w tym oświadczeniu trwającą już kilka lat rozgrywkę dyplomatyczną, stawiając sprawę jasno: Iran nie chce współpracować, ignoruje wszelkie próby rozwiązania problemu i staje się niewiarygodny. Niemniej jednak nałożone na niego obowiązki wobec ONZ i MAEA należy egzekwować, należy też dać Iranowi szansę powrotu do rokowań - jeśli faktycznie potraktuje je poważniej niż tylko jako grę na zwłokę.

W okresie negocjacji dyplomacja irańska bardzo sprytnie wykorzystywała brak jednomyślności w stanowisku UE. Mniejsze kraje unijne niechętnie zgadzały się na prowadzenie dialogu z Iranem przez grupę E3, która też nie była wewnętrznie spójna. Wielka Brytania stała zdecydowanie po stronie USA i w zasadzie reprezentowała ich interesy w UE. Niemcy i Francja prowadziły politykę bardziej niezależną od USA, ale też nie akceptowały budowy przez Iran broni jądrowej. $Z$ drugiej strony państwa te obawiały się osłabienia handlu z Iranem w wypadku zaostrzenia sankcji ONZ. Znamienny był fakt, iż E3 w zasadzie sama się upoważniła do negocjacji z Iranem, a pozostałe kraje, tudzież sama UE, zostały sprowadzone do roli obserwatorów, akceptujących z góry ustalenia "trójki” (Ćwioro, 2009, s. 121).

Wreszcie 7 lutego $2010 \mathrm{r}$. M. Ahmadineżad zapowiedział wzbogacanie uranu do poziomu $20 \%$ czystości, a 9 kwietnia oficjalnie zaprezentował irańskie wirówki „trzeciej generacji", mające przyspieszyć ten proces. Z kolei 18 lutego nowy dyrektor generalny MAEA Yukiyi Amano wydał raport, w którym zawarł ostrzeżenie, że Iran może już

${ }^{29}$ Chodzi o przytoczoną wyżej rezolucjęz 16 listopada 2009; 27 listopada jest datąjej odtajnienia. 
pracować nad głowicą bojową (IAEA, 2010a). Aby odeprzeć zarzuty o ignorowanie społeczności międzynarodowej, Iran sam wystapił z pojednawczą inicjatywą i 17 maja podpisał z Turcją i Brazylią porozumienie o zdeponowaniu w Turcji $1200 \mathrm{~kg}$ swojego nisko wzbogaconego uranu w zamian za $120 \mathrm{~kg}$ uranu wzbogaconego do $20 \% \mathrm{ma}$ jącego zasilać teherański reaktor badawczy. MAEA w raporcie z 31 maja szacowała, że Iran posiada już niemal 2,5 tony nisko wzbogaconego uranu (IAEA, 2010b), a RB ONZ uznała ofertę Teheranu za niewystarczającą i 9 czerwca przyjęła rezolucję nr 1929 z czwartą serią sankcji (UN, 2010). Sankcje te objęły m.in. poszerzenie embarga zbrojeniowego, zamrożenie zagranicznych aktywów kolejnych 15 firm i upoważnienie państw do inspekcji podejrzanych transportów do i z Iranu ${ }^{30}$.

Szczyt RE z 17 czerwca 2010 r. odniósł się do sytuacji w obszernym „Oświadczeniu w sprawie Iranu” (RE, 2010): „RE podkreśla swój rosnący niepokój w związku z realizacją przez Iran programu jądrowego i wyraża uznanie z powodu przyjęcia przez RB ONZ rezolucji nr 1929 wprowadzającej nowe środki ograniczające przeciwko Iranowi. RE z zadowoleniem przyjmuje niedawne starania poczynione przez Brazylię i Turcję [...]. RE apeluje do Iranu o przystapienie do negocjacji na temat jego programu jądrowego $^{31}$. [...] RE wyraża głębokie ubolewanie w związku z tym, że Iran nie skorzystał z licznych oferowanych mu okazji do rozwiania obaw społeczności międzynarodowej dotyczących charakteru jego programu jądrowego. Podjęta przez Iran decyzja o wzbogacaniu uranu do poziomu 20 procent [...] sprawiła, że obawy te nasiliły się [...]. W tej sytuacji nieuniknione stało się wprowadzenie nowych środków ograniczających. $[\ldots]^{32}$. RE ponownie potwierdza zobowiązanie UE do wypracowania dyplomatycznego rozwiązania kwestii programu jądrowego Iranu [...]; Rada potwierdza aktualność propozycji przedstawionych Iranowi w czerwcu 2008 r. [...]”.

Stanowisko UE było jednoznaczne: Iran musi ponieść konsekwencje swoich działań. UE chętnie zaakceptowałaby budowę przez ten kraj pokojowego potencjału nuklearnego (do czego ma prawo), ale odrzucanie przez Iran licznych międzynarodowych ofert, a także działania zmierzające do zachowania możliwości budowy broni nuklearnej - wskazywały, że nie to jest jego głównym celem. Pozostawały więc sankcje - decyzją Rady z 26 lipca 2010 r. UE przyjęła wobec Iranu jeszcze dalej idące restrykcje niż

30 Funkcjonowanie, powołanego na mocy Rezolucji nr 1929, Panelu Ekspertów, badającego sytuację w Iranie i doradzającego RB ONZ jakie dalsze kroki podejmować, było następnie przedhużane w 2011 i 2012 r.: Resolution 1984 (2011) Adopted by the Security Council at its 6552th meeting, on 9 June 2011, United Nations S/RES/1984 (2011), Security Council, Distr.: General, 9 June 2011; Resolution 2049 (2012) Adopted by the Security Council at its 6781 th meeting, on 7 June 2012, United Nations S/RES/2049 (2012), Security Council, Distr.: General, 7 June 2012.

31 Tym samym UE uznawała inicjatywę Brazylii i Turcji za wynikająca z dobrych intencji i w swoim zamierzeniu nieco zmniejszającą napięcie międzynarodowe, natomiast reakcję na nią Iranu - za unik przed wykonaniem nałożonych na niego obowiązków. Ten komentarz ujednoznaczniał rezolucję $\mathrm{nr} 1929$.

32 Pominięto obszerny fragment, wymieniający zagadnienia, w których UE gotowa byłaby prowadzić negocjacje - i ewentualnie zaostrzać sankcje. Były one nader rozlegle, obejmowały m.in. handel (szczególnie technologiami podwójnego zastosowania), kwestii zamrażania aktywów irańskich banków, irański sektor transportu kluczowe sektory przemysłu gazowego i naftowego, nowe zakazy wydawania wiz i zamrażanie aktywów, szczególnie w stosunku do Korpusu Strażników Rewolucji Islamskiej. 
RB ONZ, zabraniając m.in. „sprzedaży, dostarczania lub przekazywania - przez obywateli państw członkowskich lub z terytoriów państw członkowskich, lub przy użyciu statków lub statków powietrznych podlegających ich jurysdykcji [...] - kluczowego sprzętu i technologii dla [...] kluczowych sektorów przemysłu naftowego i gazu ziemnego w Iranie lub dla przedsiębiorstw irańskich lub należących do Irańczyków [...] poza Iranem" (art. 4 decyzji) ${ }^{33}$. Ta decyzja faktycznie szkodziła irańskiej gospodarce, utrudniając pozyskiwanie jej podstawowego towaru eksportowego - surowców energetycznych (Giumelli, 2013, s. 28).

Tymczasem Iran kontynuował swój program nuklearny: w połowie sierpnia $2010 \mathrm{r}$. oświadczył, iż zbuduje trzeci zakład wzbogacania uranu, a 21 sierpnia rozpoczął uruchamianie elektrowni atomowej w Bushehr (zbudowanej przy znacznej pomocy Rosjan). Nieoczekiwanie jednak okazało się, że jego program może trafić na problemy zupełnie nowego typu - sabotaż ze strony Izraela. Być może najcięższym ciosem w irański program nuklearny, cofającym go o kilka lat, był atak wirusa komputerowego, o którego napisanie podejrzewano służby izraelskie ${ }^{34}$. Na przełomie 2010 i 2011 roku perspektywa zbudowania bomby atomowej przez Iran oddaliła się o kilka lat.

UE zaostrzyła sankcje: 11 kwietnia 2011 r. przyjęła Decyzję Rady nr 235 o indywidualnej odpowiedzialności za tłumienie przez irańskie władze demokratycznych protestów i o wstrzymaniu eksportu wyposażenia, które mogło być stosowane przez aparat państwa ${ }^{35}$.

RE na szczycie 23 października 2011 r. (RE, 2011a) w części IV Konkluzji „Polityka Zagraniczna” (pkt 18) stwierdzała: „RE z zadowoleniem odnotowuje zaostrzenie unijnych środków ograniczających przeciwko Iranowi w odpowiedzi na niedopuszczalne przypadki łamania praw człowieka [...]. Wyraża swoje nieustanne zaniepokojenie rozwojem irańskiego programu jądrowego i programu rakietowego, wbrew rezolucjom RB ONZ i MAEA, jak również brakiem współpracy Iranu z MAEA w zakresie rozwiązywania nierozstrzygniętych kwestii, w tym kwestii wskazujących na możliwe wojskowe aspekty irańskiego programu jądrowego. Stanowczo wzywamy Iran, by podjął konstruktywne i merytoryczne rozmowy z grupą E3+3, [...] co pozwoli uniknąć dalszych środków ograniczających [...]. Potwierdza zobowiązanie UE do działania na rzecz dyplomatycznego rozwiązania tej kwestii”.

Kwestia programu nuklearnego Iranu ponownie znalazła się w centrum uwagi dyplomacji międzynarodowej po tym, gdy 8 listopada 2011 r. Rada Gubernatorów MAEA wydała raport (odtajniony 18 listopada), w którym po raz pierwszy stwierdziła (wyra-

33 Decyzja Rady z dnia 26 lipca 2010 r. w sprawie środków ograniczajacych wobec Iranu i uchylajaca wspólne stanowisko 2007/I40/WPZiB, publ. Dz.Urz. UE L 195/39, z dnia 27 lipca $2010 \mathrm{r}$.

34 Wirus ten przez dhuższy czas nie dawał się wykryć, a zamiast niszczyć irańskie dane - lekko je tylko modyfikowal, co opóźniło jego wykrycie, spowodowało narastające stopniowo błędy w obliczeniach. Wirus o nazwie Stuxnet miał zawierać „,izraelski ślad” - pojawiające się w kodzie imię Estera. Stary Testament w „Księdze Estery” opisuje intrygę perskich dostojników, którzy w V w. p.n.e. postanowili skłonić króla Kserksesa do eksterminacji Żydów. Żydówka Estera, w której wcześniej zakochal się wladca, potrafiła jednak ocalić swoich rodaków i wyniszczyć ich prześladowców. Zob. „Gazeta Wyborcza”, 29.11.2010.

35 Dnia 10 października 2011 r. w Decyzji Realizującej Rady (Council Implementing Decision) 2011/670/CFSP wskazano 59 osób odpowiedzialnych w administracji Iranu. 
żając „głębokie i rosnące zaniepokojenie"), że Iran prowadził działania zmierzające do budowy nuklearnego ładunku wybuchowego (IAEA, 2011).

Konkluzje ze szczytu RE dnia 9 grudnia 2011 r. stwierdzaly (pkt 16-17) (RE, 2011b): „Przywołując konkluzje z 23 października 2011 r. i zatwierdzając konkluzje Rady z 1 grudnia, RE ponownie wyraża poważne i coraz głębsze zaniepokojenie charakterem programu jądrowego Iranu, o czym mowa w najnowszym sprawozdaniu MAEA, jak również niewywiązywaniem się przez Iran z jego zobowiązań międzynarodowych. RE $\mathrm{z}$ zadowoleniem przyjmuje osiaggnięte na forum Rady porozumienie w sprawie wyznaczenia 180 nowych podmiotów i osób bezpośrednio związanych z programem jądrowym [...]. RE potwierdza dhugofalowe zaangażowanie UE na rzecz wypracowania dyplomatycznego rozwiązania irańskiej kwestii jądrowej [...]".

Na początku 2012 r. UE podjęła radykalną decyzję: 23 stycznia wprowadziła zakaz importu irańskiej ropy naftowej ${ }^{36}$. Państwa członkowskie zobowiązały się do zakończenia wszelkich kontraktów paliwowych z Iranem i nieprzystępowania do żadnych nowych umów. Embargiem objęto importy ropy naftowej, produktów ropopochodnych i petrochemicznych, a także sprzętu i technologii wydobywczych. Ponadto zamrożono aktywa Centralnego Banku Iranu w europejskich bankach, a 15 marca 2012 r. wykluczono Iran z globalnego systemu bankowego SWIFT, co blokowało przepływy finansowe pomiędzy bankami irańskimi a zagranicznymi. Sankcje te, stopniowo wchodzące w życie do 1 lipca 2012 r., głęboko destabilizowały irańską gospodarkę i finanse. Pod tym naciskiem Iran zaczął szukać kompromisu, proponując wznowienie negocjacji - do rozmów doszło 14 kwietnia 2012 r. w Stambule; kolejne rundy odbyły się w Bagdadzie (23-24 maja) i w Moskwie (18-19 czerwca), ale wciąż nie przyniosły rezultatów ${ }^{37}$.

Szczyt RE w dniach 28-29 czerwca 2012 r. stwierdzał (część IV „Sprawy Inne”, lit. f. „Iran”) (RE, 2012a): „RE podkreśliła swoje poważne zaniepokojenie charakterem irańskiego programu jądrowego i pilną potrzebę wypełnienia przez Iran jego wszystkich zobowiązań międzynarodowych, w tym pełnego wdrożenia przez Iran rezolucji RB ONZ i Rady Zarządzającej MAEA. RE w pełni popiera wysiłki WP SZiPB i grupy E3+3 w tym zakresie. [...] Rada wzywa Iran do podjeccia decyzji, czy ma zamiar zaangażować się w poważne negocjacje mające na celu odbudowę zaufania w wyłącznie pokojowy charakter irańskiego programu jądrowego. [...] RE z zadowoleniem przyjmuje fakt, że od 1 lipca $2012 \mathrm{r}$. w pełni wejdzie w życie embargo UE na irańską ropę, ${ }^{\text {38 }}$.

W kwestii Iranu UE w tym okresie wydawała się być znacznie bardziej zdecydowana niż Stany Zjednoczone, mimo że ze względu na dużo większe powiązania gospodarcze ponosiła większe koszty wprowadzanych sankcji. Szczególnie twardo brzmiało „kurtuazyjne” zakończenie przytoczonego fragmentu konkluzji.

36 Decyzja Rady 2012/35/WPZiB z dnia 23 stycznia 2012 r. zmieniajaca decyzję 2010/413/WPZiB w sprawie środków ograniczajacych wobec Iranu, publ. Dz.Urz. UE L 19, 24 stycznia 2012 r., s. 22.

37 Statement by High Representative Catherine Ashton on behalf of E3+3 following Talks with Iran in Moscow, 18-19 June 2012, http://www.consilium.europa.eu/uedocs/cms_Data/docs/pressdata/EN/foraff/131067.pdf, 2013.01.07.

${ }^{38}$ Zwraca uwagę lokalizacja tego fragmentu - poświęcony wszystkim sprawom międzynarodowym fragment konkluzji nazwano „Inne Kwestie”, deprecjonując jego znaczenie - a w tym kwestię Iranu. 
Na kolejnym szczycie, w dniach 18-19 października 2012 r. RE podkreśliła (pkt 20) (RE, 2012b): ,[...] swoje poważne i pogłębiające się zaniepokojenie irańskim programem jądrowym [...]. RE przypomina, że działania Iranu rażąco naruszają jego zobowiązania międzynarodowe i że kraj ten odmawia pełnej współpracy z MAEA [...] w pełni popiera działania w tym zakresie prowadzone przez WP SZiPB w imieniu grupy E3+3 mające na celu sprawienie, by Iran przystapił do merytorycznych i konstruktywnych dyskusji [...]".

Pod koniec 2012 r. polityka UE była więc wyklarowana - wciąż pozostawały otwarte możliwości dialogu, ale Iran musiał poważnymi i konkretnymi działaniami wykazać, wolę współpracy z MAEA i honorowania prawa międzynarodowego.

\section{Wymuszony kompromis}

W konkluzjach RE z 2013 i 2014 r. kwestia Iranu nie pojawia się w ogóle. To osłabienie międzynarodowej aktywności UE można thumaczyć skupieniem się na przełamywaniu kryzysu finansowego (przebiegającego ciężej niż w innych regionach). Trafniejsze będzie jednak chyba uznanie, że po określeniu swojego stanowiska UE „oddała pole" pozostałym mocarstwom - zwłaszcza USA. Zmieniła się natomiast sytuacja w Iranie - w sierpniu 2013 r. prezydentem tego kraju został Hasan Rouhani, znacznie bardziej ugodowy niż jego poprzednik. Skutek odnosiły też dotkliwe dla irańskiej gospodarki sankcje gospodarcze (sam sektor naftowy stracić miał w 2012 r. 40 mld dolarów). Zmieniła się też sytuacja międzynarodowa - na Bliskim Wschodzie pojawiały się grupy ekstremistów islamskich (zalążki przyszłego Państwa Islamskiego), wobec których Iran mógł się stać sojusznikiem państw zachodnich.

Negocjacje wznowiono jesienią 2013 r., serią nieformalnych spotkań dyplomatów USA i Iranu ${ }^{39}$. Dnia 24 listopada w Genewie zawarto umowę o wyhamowaniu przez Iran programu atomowego. Teheran zobowiazzał się wzbogacać uran tylko do poziomu $5 \%$, zniszczyć wszystkie zasoby uranu o wyższym wzbogaceniu i zaprzestać instalowania nowych wirówek do jego produkcji. Porozumienie miało obowiązywać od 20 stycznia 2014 r. przez sześć miesięcy, a w tym czasie miał być wynegocjowany układ ostateczny. W zamian za ustępliwość irańską delegację zaproszono w 2014 r. na Forum Ekonomiczne w Davos, a także na konferencję pokojową poświęconą wojnie domowej w Syrii - w Genewie.

Tymczasem negocjacje nad ostatecznym porozumieniem znów utknęły. W połowie 2014 r. ostateczny termin zawarcia porozumienia zostal przesunięty z 20 lipca na 24 listopada. Duża ilość szczegółów, upór ze strony Iranu, zmieniająca się sytuacja międzynarodowa (powstanie i ekspansja Państwa Islamskiego od połowy 2014 r.) oraz rozbieżności $\mathrm{w}$ grupie sześciu mocarstw utrudniały zakończenie rokowañ ${ }^{40}$.

39 Atomowe porozumienie w Genewie poprzedzily tajne negocjacje USA-Iran, 25.11.2013, $\mathrm{http}: / / \mathrm{www}$.polskieradio.p1/5/3/Artykul/985897,A tomowe-porozumienie-w-Genewie-poprzedzily-tajne-negocjacje-USA-Iran, 7 maja 2015.

40 Zasiadająca w gronie mocarstw Rosja od wiosny 2014 r. sama była okladana sankcjami międzynarodowymi za interwencję na Ukrainie i aneksję Krymu. Jej gospodarka, uzależniona w znacznej 
Na początku września MAEA poinformowała, że Iran nie złożył koniecznych wyjaśnień na temat swego programu nuklearnego i wprowadził w życie tylko trzy z pięciu obiecanych przedsięwzięć na rzecz transparentności tego programu. Jesienią $2014 \mathrm{r}$. Stany Zjednoczone dawały do zrozumienia, że zgodziłyby się nawet na częściowe (zamiast całkowitego) porozumienie - jeśli dałoby się taki układ przyjąć szybko. Z kolei pod koniec 2014 r. nastąpiły personalne zmiany w strukturach UE: dnia 1 listopada szefem Rady Europejskiej został b. polski premier Donald Tusk, a unijną WP SZiPB - Włoszka Federica Mogherini.

Wstępne porozumienie zostało wynegocjowane 2 kwietnia 2015 r. w Lozannie. Zakładało ono, że irańskie zdolności wzbogacania uranu zostaną ograniczone o ponad 2/3: z posiadanych ok. 19 tys. wirówek Iran zachować miał ok. 6 tys. Teheran zgodził się przez co najmniej 15 lat nie wzbogacać uranu powyżej poziomu 3,67\%, ani nie budować żadnych nowych obiektów służących temu celowi. Przez kolejne 25 lat byłyby prowadzone inspekcje irańskiego łańcucha dostaw uranu. Porozumienie dawało inspektorom ONZ „,uregulowany dostęp” do obiektów wojskowych i możliwość pobierania tam próbek - pod irańską kontrolą. W zamian amerykańskie i europejskie sankcje nałożone na Teheran byłyby uchylane. F. Mogherini w imieniu UE zastrzegła, że byłby to proces stopniowy, paralelny do wykonywania przez Iran jego zobowiązań. Dodała też, że finalne porozumienie nuklearne będzie wymagało zatwierdzenia przez RB ONZ. Natomiast sankcje USA nałożone uprzednio na Iran za terroryzm, łamanie praw człowieka i używanie pocisków balistycznych - obowiązywałyby nada $1^{41}$.

Przed finalnym porozumieniem (planowanym na 30 czerwca 2015 r.) trwała wojna nerwów - i tak 21 czerwca irański parlament przyjął ustawę zabraniającą MAEA dostępu do irańskich obiektów wojskowych, a także kontrolowania irańskich naukowców ${ }^{42}$.

Ostateczne porozumienie, na bazie ustaleń z 2 kwietnia, zostało wynegocjowane 14 lipca 2015 r. w Wiedniu, pod nazwa JCPOA (Joint Comprehensive Plan of Action - Wspólny Kompleksowy Plan Dzialania ${ }^{43}$. Ogłosili je wspólnie F. Mogherini i szef irańskiej dyplomacji Mohammad Dżawad Zarif. We wstępie i w preambule dokumentu (liczącego 159 stron) Iran zapewnił, że w żadnych warunkach ani okolicznościach nie będzie starał się wyprodukować ani pozyskać broni atomowej.

Przez 15 lat Iran nie będzie mógł posiadać więcej niż $300 \mathrm{~kg}$ uranu wzbogaconego do poziomu 3,67\% - nadwyżki musi sprzedać (w połowie $2015 \mathrm{r}$. miał niemal 8 ton). Natomiast uran wzbogacony w granicach 5-20\% musi zostać przerobiony na surowiec

mierze od eksportu nośników energii mogła tylko ucierpieć, jeśli negocjacje z Iranem zakończyłyby się sukcesem i ten kraj zacząlby eksport wlasnej ropy i gazu.

${ }^{41}$ Zob. IAEA, BoG, Implementation of the NPT Safeguards Agreement and relevant provisions of Security Council resolutions in the Islamic Republic of Iran, Report by the Director General, GOV/2015/34, Date: 29 May 2015, Derestricted 11 June 2015.

42 Iran zdecydowal, nie wpuści kontrolerów. Co $z$ atomowym porozumieniem?, 24.06.15, http://www.polskieradio.pl/5/3/Artykul/1467240,Iran-zdecydowal-nie-wpusci-kontrolerow-Co-z-atomowym-porozumieniem, 31 lipca 2015 r.; Ostatni moment na zawarcie porozumienia z Teheranem. Szef MSZ Iranu: rozmowy nuklearne potrwajajeszcze w weekend, 10.07.2015, http://www.polskieradio.pl/5/3/Artykul/1473607, Ostatni-moment-na-zawarcie-porozumienia-z-Teheranem-Szef-MSZ-Iranu-rozmowy-nuklearne-potrwaja-jeszcze-w-weekend, 31 lipca 2015 r.

43 Osiagnięto porozumienie nuklearne z Iranem, „Rzeczpospolita”, 14.07.2015, http://www.rp.pl/ artykul/70215,1215402-Osiagnieto-porozumienie-nuklearne-z-Iranem.html, 31 lipca 2015 r. 
o mniejszym stopniu nasycenia. Przez 10 lat wykluczona jest produkcja plutonu. Iran, choćby chciał, nie będzie w stanie zbudować nawet jednej głowicy nuklearnej w czasie krótszym niż rok. Porozumienie daje inspektorom ONZ dostęp do irańskich instalacji wojskowych - jest to duże ustępstwo Iranu, który do tej pory kategorycznie sprzeciwiał się wszelkim takim wizytom. Inspekcje wymagać będą każdorazowej akceptacji rządu w Teheranie, który otrzyma także możliwość odwołania się do rady arbitrażowej, w składzie przedstawicieli sześciu mocarstw i Iranu. W przypadku nieuzasadnionego uniemożliwienia inspekcji po próbach ustalenia ich terminu, międzynarodowe sankcje zostaną automatycznie przywrócone. Strony porozumiały się także w sprawie utrzymania nałożonego na Iran przez ONZ embarga: przez 5 lat na broń, a do 8 lat na pociski rakietowe. Szczegółowych regulacji jest wiele: od likwidacji wirówek służących do wzbogacania uranu po likwidację irańskich zapasów takiego uranu. Równocześnie Iran może bez przeszkód rozwijać energetykę nuklearną, a jego instalacje nuklearne nie muszą być demontowane (Jendroszczyk, 2015).

Znoszenie sankcji wobec Iranu umożliwia mu zarówno eksport ropy naftowej, jak i przygotowanie się do konwencjonalnej modernizacji armii. Bezpośrednim wynikiem podpisania porozumienia był znaczący spadek cen ropy naftowej, której Iran jest czołowym eksporterem. Dzięki porozumieniu, irańska gospodarka może zyskać około 100 mld dolarów dzięki odmrożeniu zagranicznych aktywów, które zostały zablokowane na mocy sankcji. Najbardziej pro irańska w gronie sześciu mocarstw Rosja ogłosiła, że jest gotowa dostarczyć Iranowi nieobjęty embargiem system antyrakietowy S-300, inne kraje są gotowe unowocześniać jego lotnictwo (Tomański, 2015). Rosja zapowiedziała też, że będzie sprowadzać z Iranu nisko wzbogacony uran w zamian za uran naturalny, pomoże też w produkcji izotopów dla celów przemysłowych i medycznych.

Porozumienie zostało zawarte mimo wyraźnego sprzeciwu Izraela, obawiającego się kontynuacji przez Iran programu nuklearnego. Władze Izraela zapowiedziały podjęcie działań zmierzających do tego, by nie dopuścić do jego ratyfikowania. Ma ono również wielu przeciwników w amerykańskim Kongresie - republikanie, którzy są w opozycji wobec prezydenta B. Obamy uważają, że możliwa była lepsza (ściślej kontrolująca Iran) umowa.

Dnia 20 lipca 2015 r. porozumienie zaakceptowała RB ONZ.

\section{Podsumowanie}

W wypadku stosunków z Iranem można byłoby znaleźć korelację zmiany polityki UE - z wejściem w życie Traktatu lizbońskiego (końcówka 2009 r.). Znacznie większy wpływ na usztywnienie unijnej polityki miało jednak coraz bardziej asertywne działanie Iranu. W II połowie 2009 r. społeczność międzynarodowa przekonała się, że program atomowy nie jest jedynie fanaberią epizodycznego przywódcy, który skończy się wraz z jego odejściem ${ }^{44}$. Reelekcja M. Ahmadineżada, poparcie jakie uzyskał oraz towej".

44 Tak jak koniec prezydentury G. W. Busha zamknąl jego koncepcję budowy „tarczy antyrakie- 
ujawnione jesienią 2009 r. zaawansowanie prac - zmusiły UE do bardziej zdecydowanych reakcji (Giumelli, 2013, s. 29).

Polityka UE wobec tego kryzysu cechowała się (Parsi, 2013, s. 21-22):

- pełną koordynacją działań z innymi podmiotami międzynarodowymi: ONZ, MAEA i partnerami z grupy E3+3;

- dominacja polityki unijnych mocarstw - to one wchodziły w skład grupy E3+3;

- powierzaniem instytucjom UE (jak Wysokiemu Przedstawicielowi) licznych, ale stricte technicznych zadań - np. prezentowania Iranowi stanowiska społeczności międzynarodowej. Oczywiście podnosiło to formalny prestiż UE, ale nie zwiększało zbytnio jej roli w rzeczywistym rozwiązywaniu problemu ${ }^{45}$;

- szukaniem rozwiązań dyplomatycznych, gotowością do ich przyjęcia nawet za cenę naginania faktów: wobec groźby budowy irańskiego arsenału nuklearnego, nawet przymykanie oczu na regionalne aspiracje Teheranu byłoby znośną ceną za kompromis;

- wtórną i wykonawczą rolą wobec inicjatyw i postanowień innych podmiotów (zarówno USA, jak i europejskich mocarstw);

- wykorzystywaniem potencjału szantażu ekonomicznego, uruchamianego powoli i w ostateczności, ale efektywnie i z dużą precyzją.

Wobec Iranu UE starała się odgrywać rolę rozjemcy/stabilizatora oraz promotora rozbrojenia/nieproliferacji. Wynikało to z jej ogólnych założeń - dążenia do utrzymania pokoju oraz gotowości udzielania hojnej pomocy gospodarczej w razie spełnienia jej oczekiwań politycznych. Należy jednak zauważyć, że UE - mając wobec Iranu mniej środków nacisku niż USA - formułowała swoją politykę z dużymi trudnościami.

Od połowy 2013 r. wola kompromisu między Iranem a grupą E3+3 wzrastała. Jednak pierwszoplanową rolę ze strony społeczności międzynarodowej odgrywać zaczęła nie UE, ale USA. O ile UE mogła podkreślać swoje znaczenie gospodarcze (zarówno jako istotnego kreatora sankcji, jak i potencjalnego darczyńcy wobec Iranu), o tyle USA miały bardziej skonkretyzowaną wizję ładu na Środkowym Wschodzie i miejsca w nim Iranu. UE w końcowej fazie negocjacji odgrywała rolę ważną - ale wspierająca, sprzeczności interesów jej państw członkowskich i brak pełnej wizji ładu międzynarodowego w regionie utrudniały jej artykułowanie własnych oczekiwań. Popierała projekty formalnie ONZ, w praktyce - USA.

\section{Bibliografia}

Coville T. (2009), Najnowsza historia Iranu; Republika Islamska, Wydawnictwo Akademickie DIALOG, Warszawa.

45 Można analizować, dlaczego ten właśnie urzędnik został wskazany na „,negocjatora”. O ile np. Amerykanin mógłby być nie do przyjęcia dla Teheranu, a Rosjanin czy Chińczyk - byłby podejrzewany o zbytnią ustępliwość wobec Iranu, o tyle przedstawiciel UE, czyli struktury dopiero budującej swoje miejsce na arenie międzynarodowej był akceptowalny. Dodatkowo jeszcze zarówno Iran, jak i mocarstwa globalne wiedza, że UE funkcjonuje jako „mocarstwo niewojskowe”, a jej aspiracje do wzmocnienia własnej pozycji są powstrzymywane przez państwa czlonkowskie - co minimalizuje podejrzenia o prowadzenie wobec Iranu jakiejś własnej gry. 
Cwioro B. (2009), Międzynarodowe wysitki na rzecz powstrzymania irańskiego programu nuklearnego, w: Iran - 30 lat po rewolucji, Biblioteka „Bezpieczeństwa Narodowego”, t. 12, Biuro Bezpieczeństwa Narodowego, Warszawa.

Decyzja Rady z dnia 26 lipca 2010 r. w sprawie środków ograniczajacych wobec Iranu i uchylajaca wspólne stanowisko 2007/140/WPZiB, publ. Dz. Urz. UE L 195/39, z dnia 27 lipca $2010 \mathrm{r}$.

Decyzja Realizująca Rady (Council Implementing Decision) 2011/670/CFSP z dnia 10 października $2011 \mathrm{r}$.

Decyzja Rady 2012/35/WPZiB z dnia 23 stycznia 2012 r. zmieniajaca decyzję 2010/413/WPZiB w sprawie środków ograniczających wobec Iranu, publ. Dz. Urz. UE L 19, 24 stycznia 2012 r. s. 22.

Denza E. (2005), Non-prolfferation of Nuclear Weapons: The European Union and Iran, „European Foreign Affairs Review", vol. 10, no 3.

Ehteshami A. (2006), The future of Iran's defence and nuclear policy, w: Iranian challenges, red. W. Posch, „Chaillot Papers”, nr 89, May.

Farhi F. (2013), Factional politics and the Islamic State, w: Iran: a revolutionary Republic in transition, red. F. Farhi, „Chaillot Papers” nr 128, February.

Giumelli F. (2013), How EU sanctions work: a new narrative, „Chaillot Papers" nr 129, May.

Halliday F. (2006), Iran's regional and strategic interests, w: Iranian challenges, red. W. Posch. "Chaillot Papers", nr 89, May.

International Atomic Energy Agency (IAEA), Board of Governors (BoG), Report by the Director General, IAEA (2003) GOV/2003/40, Date: 6 June 2003, Derestricted 19 June 2003.

IAEA (2004), GOV/2004/34, Date: 1 June 2004, Derestricted 18 June 2004.

IAEA (2005), GOV/2005/67, Date: 2 September 2005, Derestricted 24 September 2005.

IAEA (2006), GOV/2006/53, Date: 31 August 2006, Derestricted 14 September 2006.

IAEA (2007a), GOV/2007/8, Date: 22 February 2007, Derestricted 7 March 2007.

IAEA (2007b), GOV/2007/22, Date: 23 May 2007, Derestricted 14 June 2007.

IAEA (2007c), GOV/2007/48, Date: 30 August 2007, Derestricted 12 September 2007.

IAEA (2007d), GOV/2007/58, Date: 15 November 2007, Derestricted 23 November 2007.

IAEA (2008a), GOV/2008/4, Date: 22 February 2008, Derestricted 5 March 2008.

IAEA (2008b), GOV/2008/15, Date: 26 May 2008, Derestricted 5 June 2008.

IAEA (2008c), GOV/2008/38, Date: 15 September 2008, Derestricted 24 September 2008.

IAEA (2008d), GOV/2008/59, Date: 19 November 2008, Derestricted 27 November 2008.

IAEA (2009a), GOV/2009/8, Date: 19 February 2009, Derestricted 4 March 2009.

IAEA (2009b), GOV/2009/35, Date: 5 June 2009, Derestricted 17 June 2009.

IAEA (2009c), GOV/2009/55, Date: 28 August 2009, Derestricted 9 September 2009.

IAEA (2009d), GOV/2009/74, Date: 16 November 2009, Derestricted 27 November 2009.

IAEA (2010a), GOV/2010/10, Date: 18 February 2010, Derestricted 3 March 2010.

IAEA (2010b), GOV/2010/28, Date: 31 May 2010, Derestricted 10 June 2010.

IAEA (2011), GOV/2011/65, Date: 8 November 2011, Derestricted 18 November 2011.

IAEA (2015), GOV/2015/34, Date: 29 May 2015, Derestricted 11 June 2015.

Jendroszczyk P., Iran wraca na salony, „Rzeczpospolita” 2015.07.14, http://www.rp.pl/artykul/ 70215,1215554-Porozumienie-z-Iranem.html, 25.07.2015.

Kapiszewski A. (2006), Iran's 2005 presidential elections and their impact on the Republic's politics. w: Iranian challenges, red. W. Posch, „Chaillot Papers”, nr 89, May. 
Kuźniar R. (2011), Pozimnowojenne dwudziestolecie 1989-2010; Stosunki międzynarodowe na przelomie XX i XXI wieku, Instytut Stosunków Międzynarodowych Uniwersytetu Warszawskiego, Wydawnictwo Naukowe Scholar, Warszawa.

Parsi R. (2013), Introduction: Iran at a critical juncture, w: Iran: a revolutionary Republic in transition, red. R. Parsi, „Chaillot Papers”, nr 128, February.

Posch W. (2006), The EU and Iran: a tangled Web of negotiations, w: Iranian challenges, red. W. Posch, „Chaillot Papers”, nr 89, May.

Tomański R., Kto, za ile i w co uzbroi Iran?, „Rzeczpospolita” 17.07.2015, http://www.rp.pl/artykul/ 70215,1216225-Kto--za-ile-i-w-co-uzbroi-Iran-.html, 25.07.2015.

Turczyński P. (2012), Amerykańskie koncepcje tarczy antyrakietowej w Europie, wyd. POLTEXT. Warszawa.

RE (2005a), Konkluzje Rady Europejskiej z dnia 16-17 czerwca 2005 r., RUE, Bruksela, 15 lipca 2005 r., 10255/1/05 REV 1.

RE (2005b), Konkluzje Rady Europejskiej z dnia 15 i 16 grudnia 2005 r., RUE, Bruksela, 30 stycznia 2006 r., 15914/1/05 REV 1.

RE (2006), Konkluzje Rady Europejskiej z dnia 15-16 czerwca 2006 r., RUE, Bruksela, 17 lipca 2006 r. 10633/1/06 REV 1.

RE (2006b), Konkluzje Rady Europejskiej z dnia 14-15 grudnia 2006 r., RUE, Bruksela, 12 lutego 2007 r. 16879/1/06 REV 1.

RE (2007), Konkluzje Rady Europejskiej z dnia 14 grudnia 2007 r., RUE, Bruksela, 14 lutego 2008 r. 16616/1/07 REV 1.

RE (2009a), Konkluzje Rady Europejskiej z dnia 18-19 czerwca 2009 r., RUE, Bruksela, 10 lipca 2009 r. 11225/2/09 REV 2 CONCL 2.

RE (2009b), Konkluzje Rady Europejskiej z dnia 10-11 grudnia 2009 r., RE, Bruksela, 11 grudnia 2009 r., EUCO 6/09, CO EUR 6, CONCL 4.

RE (2010), Konkluzje Rady Europejskiej z dnia 17 czerwca 2010 r., EUCO 13/10 CO EUR 9. CONCL 2.

RE (2011a), Konkluzje Rady Europejskiej z dnia 23 października 2011 r., Bruksela 30 listopada 2011 r., EUCO 52/1/11 REV 1, CO EUR 17, CONCL 5.

RE (2011b), Konkluzje Rady Europejskiej z dnia 9 grudnia 2011 r., Bruksela 25 stycznia 2012 r., EUCO 139/1/11 REV 1, CO EUR 24, CONCL 6.

RE (2012a), Konkluzje Rady Europejskiej z dnia 28-29 czerwca 2012 r., Bruksela 29 czerwca 2012 r., EUCO 76/12, CO EUR 4, CONCL 2.

RE (2012b), Konkluzje Rady Europejskiej z dnia 18-19 października 2012 r., Bruksela 19 października 2012 r., EUCO 156/12, CO EUR 15, CONCL 3.

Statement by the Iranian Government and Visiting EU Foreign Ministers, 21 October 2003, $\mathrm{http}: / /$ www.iaea.org/newscenter/focus/iaeairan/statement_iran21102003.shtml, 25.10.2012.

Statement by High Representative Catherine Ashton on behalf of E3+3 following Talks with Iran in Moscow, 18-19 June 2012, http://www.consilium.europa.eu/uedocs/cms_Data/docs/ pressdata/EN/foraff/131067.pdf, 07.01.2013.

UN (2005), Resolution adopted by the General Assembly, 60/7. Holocaust remembrance, United Nations A/RES/60/7, General Assembly Distr.: General 21 November 2005.

UN (2006), Resolution 1696 (2006) Adopted by the Security Council at its 5500th meeting, on 31 July 2006, United Nations S/RES/1696 (2006), Security Council Distr.: General, 31 July 2006.

UN (2006b), Resolution 1737 (2006) Adopted by the Security Council at its 5612th meeting, on 23 December 2006, United Nations S/RES/1737 (2006), Security Council, Distr.: General. 27 December 2006. 
UN (2007), Resolution 1747 (2007) Adopted by the Security Council at its 5647th meeting, on 24 March 2007, United Nations S/RES/1747 (2007), Security Council, Distr.: General. 24 March 2007.

UN (2008a), Resolution 1803 (2008) Adopted by the Security Council at its 5848th meeting, on 3 March 2008, United Nations S/RES/1803 (2008), Security Council, Distr.: General. 3 March 2008.

UN (2008b), Resolution 1835 (2008) Adopted by the Security Council at its 5984th meeting, on 27 September 2008, United Nations S/RES/1835 (2008), Security Council, Distr.: General. 27 September 2008.

UN (2010), Resolution 1929 (2010) Adopted by the Security Council at its 6335th meeting, on 9 June 2010, United Nations S/RES/1929 (2010), Security Council, Distr.: General, 9 June 2010.

UN (2011), Resolution 1984 (2011) Adopted by the Security Council at its 6552th meeting, on 9 June 2011, United Nations S/RES/1984 (2011), Security Council, Distr.: General, 9 June 2011.

UN (2012), Resolution 2049 (2012) Adopted by the Security Council at its 6781th meeting, on 7 June 2012, United Nations S/RES/2049 (2012), Security Council, Distr.: General, 7 June 2012.

\section{Źródła internetowe:}

Atomowe porozumienie w Genewie poprzedzily tajne negocjacje USA-Iran, 25.11.2013, http://www.polskieradio.p1/5/3/Artykul/985897,Atomowe-porozumienie-w-Genewie-poprzedzily-tajne-negocjacje-USA-Iran, 7.05.2015.

Iran zdecydowat, nie wpuści kontrolerów. Co z atomowym porozumieniem?, 24.06.2015, http://www.polskieradio.pl/5/3/Artykul/1467240, Iran-zdecydowal-nie-wpusci-kontrolerow-Co-z-atomowym-porozumieniem, 15.07.2015.

Ostatni moment na zawarcie porozumienia z Teheranem. Szef MSZ Iranu: rozmowy nuklearne potrwaja jeszcze w weekend, 10.07.2015, http://www.polskieradio.pl/5/3/Artykul/1473607,Ostatni-moment-na-zawarcie-porozumienia-z-Teheranem-Szef-MSZ-Iranu-rozmowy-nuklearne-potrwaja-jeszcze-w-weekend, 15.07.2015.

Osiagnięto porozumienie nuklearne z Iranem, ,Rzeczpospolita”, 14.07.2015, http://www.rp.pl/artykul/ 70215,1215402-Osiagnieto-porozumienie-nuklearne-z-Iranem.html, 25.07.2015.

\section{Streszczenie}

Artykuł poświęcony jest wydarzeniom lat 2005-2015, kiedy to społeczność międzynarodowa uznała, że rozwijany przez Iran program nuklearny może służyć także celom wojskowym i podjęła starania o poddanie tego programu ścisłej kontroli. Szczególnie aktywna była na tym polu dyplomacja Unii Europejskiej i jej trzech najsilniejszych państw: Francji, Niemiec i Wielkiej Brytanii. Wobec sprzeciwu Iranu i przyspieszania jego prac możliwa była albo droga konfrontacji (również militarnej), albo zrekompensowania Irańczykom rezygnacji z aspiracji nuklearnych. W kilkuletnich negocjacjach, zakończonych porozumieniem w lipcu 2015 r., UE potrafiła z jednej strony wywrzeć silną presję polityczno-gospodarczą na Iran, a z drugiej - zaoferować mu korzystne warunki współpracy w badaniach atomowych.

Slowa kluczowe: Iran, UE, negocjacje międzynarodowe, energia atomowa, broń jądrowa 
The role of the European Union in the negotiations on Iran's nuclear programme

\section{Summary}

The paper discusses the events of 2005-2015, when the international community decided that Iran's nuclear programme can also serve military purposes, and endeavoured to impose a strict control over this programme. The diplomacy of the European Union was exceptionally active in this area, in particular its three strongest members: France, Germany and the United Kingdom. Given the protests of Iran and its accelerated work within the programme, there emerged the option of confrontation (including military conflict) or compensation offered to Iran in return for its abandoning nuclear ambitions. Over several years of negotiations, concluded by an agreement in July 2015, the EU was able to exert a strong politico-economic pressure on Iran on the one hand, and offer it advantageous terms of cooperation in the field of nuclear research on the other.

Key words: Iran, EU, international negotiations, nuclear energy, nuclear weapons 